\title{
Analyzing Preferred Indoor Ornamental Potted Plants for Their Air Pollution Tolerance Ability
}

\author{
Shivani Chauhan', Manisha ${ }^{1}$, Bhavya Bhargava ${ }^{2}$, Kishor Chandra Kandpal ${ }^{1,3}$, \\ Amit Kumar ${ }^{1 *}$
}

${ }^{1}$ RS-GIS Laboratory, Environmental Technology Division, CSIR-Institute of Himalayan Bioresource Technology, Palampur, Himachal Pradesh - 176061, India

${ }^{2}$ Agrotechnology Division, CSIR-Institute of Himalayan Bioresource Technology, Palampur, Himachal Pradesh - 176061, India

${ }^{3}$ Academy of Scientific and Innovative Research (AcSIR), CSIR-HRDC Campus, Ghaziabad, Uttar Pradesh - 201002, India

Received: 7 April 2021

Accepted: 17 July 2021

\begin{abstract}
Ornamental potted indoor plants provide environment friendly, self-regulating and cost-effective solutions to ameliorating indoor air pollution. The present study aimed to measure Air Pollution Tolerance Index (APTI) of 15 commonly used indoor ornamental plant species. APTI was measured from the foliar portion of plants using their 04 biochemical parameters like chlorophyll (total), $\mathrm{pH}$, relative water content, and ascorbic acid. It was found that among all plant species, Dracaena deremensis (APTI 13.03) and Ficus benjamina (APTI 12.19) appeared as tolerant; eight species (Spathiphyllum wallisii, Epipremnum aureum, Philodendron bipinnatifidum, Dieffenbachia seguine, Sansevieria trifasciata, Hedera helix, Chrysanthemum indicum, Ficus elastica) were moderately tolerant with APTI values ranging from 11.40 to 10.70. The Chlorophytum comosum (APTI 10.32) was intermediately tolerant and four were sensitive (Rhapis excels APTI 8.58, Chamadorea seifrizii APTI 8.47, Dypsis lutescens APTI 7.47, Gerbera jamesonii APTI 6.76) towards air pollution. A positive and high correlation was obtained between APTI and RWC $\left(\mathrm{R}^{2}=0.742\right)$, and APTI and Ascorbic acid $\left(\mathrm{R}^{2}=0.615\right)$. The present study thus helped in knowing the pollution tolerance abilities of widely used indoor potted ornamental plants. It was also revealed that the evaluation of the plant tolerance index could be useful for the screening of appropriate indoor plant species for pollution abatement.
\end{abstract}

Keywords: APTI, bio-indicators, indoor potted plants, indoor air pollutants, pollution abatement

*e-mail: amitkr@ihbt.res.in 


\section{Introduction}

In recent years, the deterioration of indoor air quality due to air pollution has become a major health issue globally. Nowadays, people usually spend about $90 \%$ of their time inside their buildings, where they have a chance to get exposed to varieties of indoor pollutants released by various appliances and decor [1]. In several studies conducted on indoor and outdoor air qualities, higher concentration of air pollutants was observed in indoor air as compared to outdoor [2]. Inadequate ventilation due to congestion in the offices and home buildings lead to an easy accumulation of indoor air pollutants to dangerous levels [3]. Such accumulation of indoor air pollution also contributes significantly to a detrimental impact on human health that causes chronic disease such as sick building syndrome [4]. Household air pollution is a type of Indoor Air Pollution (IAP) creating environmental risks causing approximately 4.3 million deaths per annum globally (5). As per Global Burden of Disease report, in 2017, 1.6 million people prematurely died as a consequence of IAP, of which India alone accounted for $28 \%$ of such deaths, which is highest among developing countries. Ironically, in a country like India, the Air pollution act which was formulated in 1981 and later revised in 2009 (www.envfor.nic.in/legis/air/airl.html) deals with outdoor air pollution and doesn't have mention of indoor air pollution [6].
It is well acknowledged that plants provide most promising and natural way of cleansing the indoor atmosphere [7]. Plants play a critical role in retaining and regulating the ecological balance, especially the leaves have ample region for impinging, absorbing and gathering the air pollutants, thus reducing the level of pollutants $[8,9]$. Numerous species of herbs, shrubs and trees have been reported to improve indoor air quality by absorbing particulate and gaseous pollutants [10]. A variety of ornamental potted plants are also capable of absorbing volatile organic compounds (VOCs) present in the indoor air [11]. Decorating workplaces or homes with suitable plants will reduce the degree of distress caused by indoors air contaminators [12]. Responses of vegetation to air pollution are evaluated by the Air Pollution Tolerance Index (APTI) which indicates the potential of plants to fight air pollution [13-15]. APTI is derived from 01 physiological (relative water content) and 03 biochemical parameters such as total chlorophyll, ascorbic acid, $\mathrm{pH}[16,17]$.

It is thus evident that the outdoor air pollution receives more attention as compared to indoor air pollution, when it comes to its control, though high concentrations of pollutants are also observed in the indoor air. Also, several studies have been reported for deriving APTI values of tree species and studies on APTI for indoor plants are negligible. Therefore, this study was conducted on 15 preferred indoor plants (Table 1) to know their ability potential

Table 1. Details of indoor plants used for APTI assessment.

\begin{tabular}{|c|c|c|c|c|}
\hline S.No. & Common Name & Scientific Name & Family & Photograph \\
\hline 1 & Weeping fig & Ficus benjamina L. & Moraceae & \\
\hline 2 & Snake plant & Sansevieria trifasciata Prain & Asparagaceae & \\
\hline 3 & Spider plant & Chlorophytum comosum (Thunb.) Jacques & Asparagaceae \\
\hline & & & & \\
\hline
\end{tabular}


Table 1. Continued.

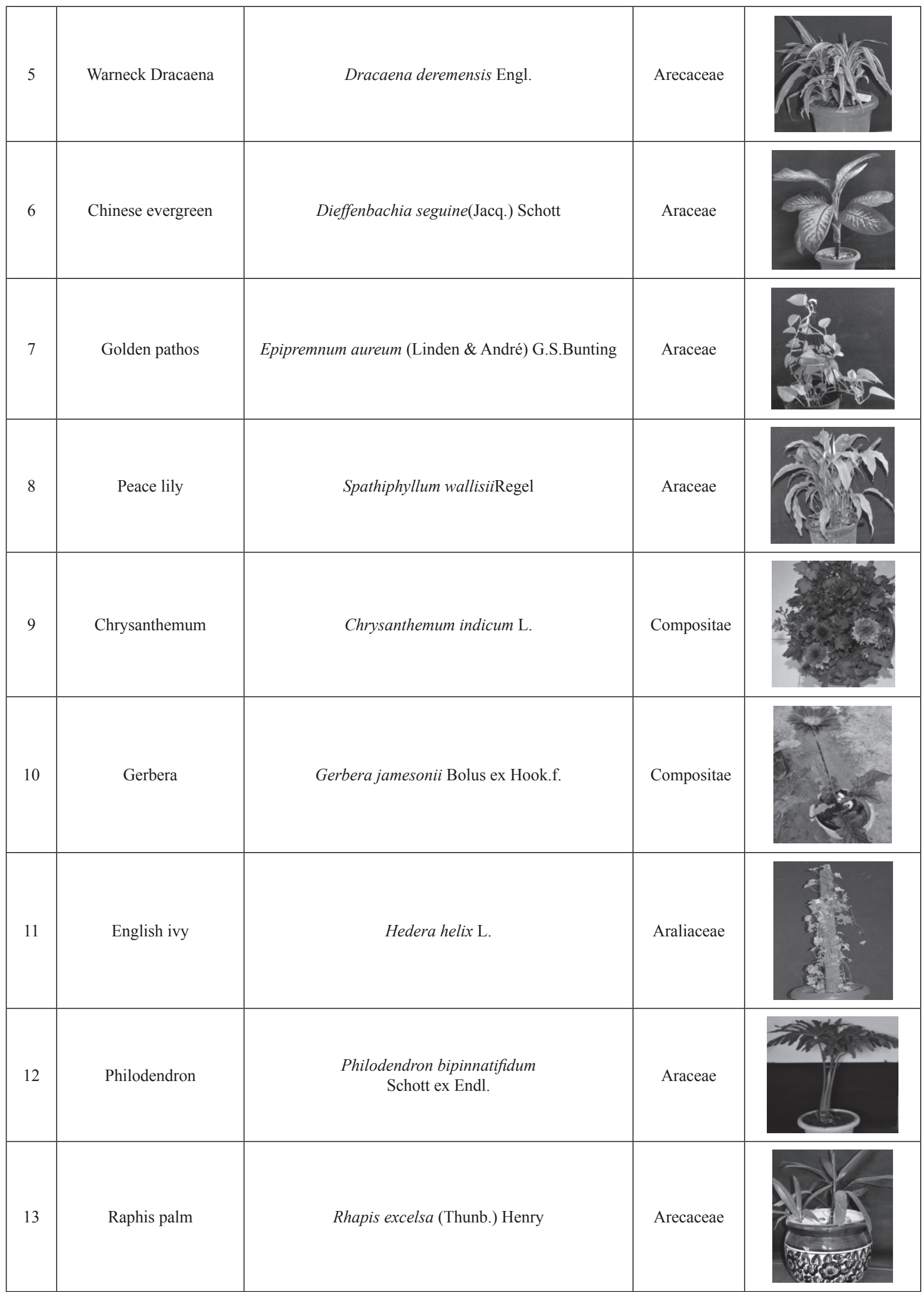


Table 1. Continued.

\begin{tabular}{|c|c|c|c|}
\hline 14 & Bamboo palm & Chamaedorea seifriziiBurret & Arecaceae \\
\hline 15 & Rubber plant & Ficus elastica Roxb. Ex Hornem. & Moraceae \\
\hline
\end{tabular}

to tolerate indoor pollution. Poor indoor air quality problem can be combated by planting tolerant indoor plant species having high APTI value. The study thus aimed to determine the sensitivity/tolerance of above indoor plants towards air pollution by deriving their APTI values.

\section{Material and Methods}

This study was conducted at CSIR-Institute of Himalayan Bioresource Technology, Palampur, Himachal Pradesh, India. It is located at $1395 \mathrm{~m}$ a.s.l.

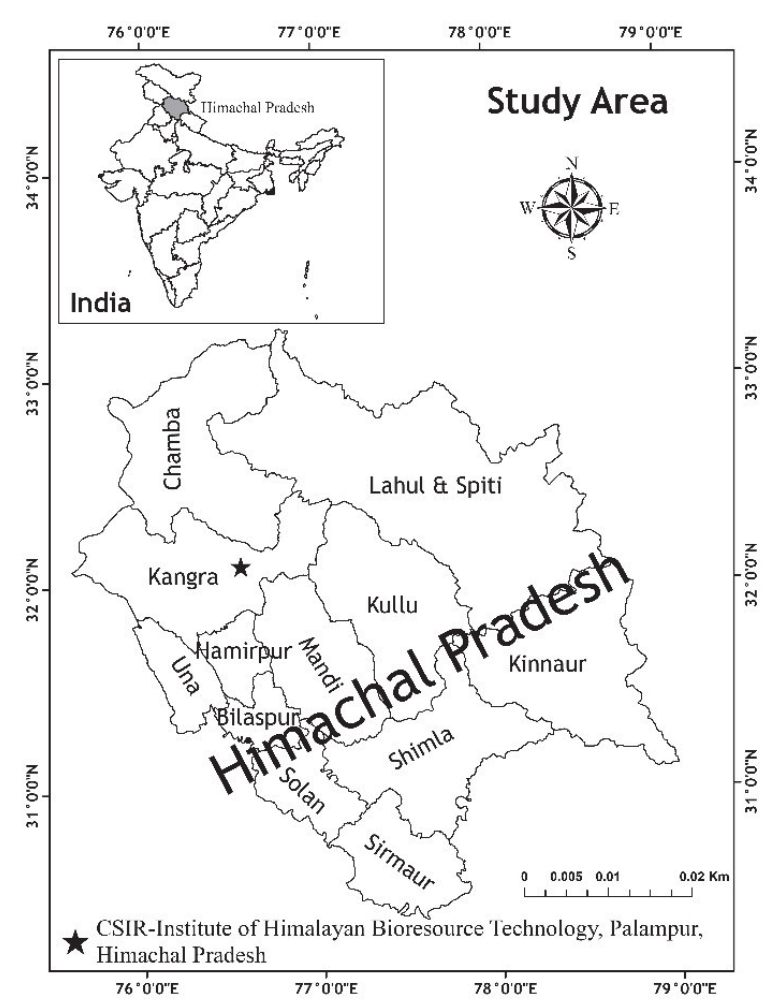

Fig. 1. Study area map. in foothills of Indian north-western Himalaya extending from latitude $32^{\circ} 06^{\prime} \mathrm{N}$ to longitude $76^{\circ} 34^{\prime} \mathrm{E}$ (Fig. 1).

Fully grown indoor ornamental potted plants of 15 species (Table 1) were selected from the recommended list of State Pollution Control Board, Government of Himachal Pradesh, India (https://hppcb.nic.in) under Pollution Abating Plants Abhiyan (PAPA). These plants require less maintenance, suitable for indoor environment and have well-documented role in pollutants eradication [18].

Biochemical parameters were estimated using healthy and matured leaves plucked from top of the shoots from 03 plants for estimating the average (Fig. 2). Total Chlorophyll (T Chl) was estimated in the laboratory using $1 \mathrm{gm}$ fresh leaves crushed with $80 \%$ acetone and its spectrophotometer absorbance at $645 \mathrm{~nm}$ and $663 \mathrm{~nm}$ following Arnon's equation [19]. The leaf extract $\mathrm{pH}$ was estimated using a $\mathrm{pH}$ meter from $5 \mathrm{~g}$ of fresh leaves homogenized in $20 \mathrm{ml}$ double distilled water. This mixture was filtered and $\mathrm{pH}$ was determined after calibrating $\mathrm{pH}$ meter with $\mathrm{pH}$, pH 9 and pH 7 buffer solutions. Relative Water Content (\%) was estimated using turgid and dry weight of $5 \mathrm{~g}$ chopped leaf samples [20]. The '2, 6 DichlorophenolIndophenol Visual Titration method' was used for calculating Ascorbic Acid (AA) [21]. APTI was calculated $[22,23]$ using values of the above parameters with the help of following formula:

$$
A P T I=\frac{[A(T+P)+R]}{10}
$$

where, $\mathrm{A}=$ ascorbic acid $(\mathrm{mg} / \mathrm{g}), \mathrm{T}=$ total chlorophyll $(\mathrm{mg} / \mathrm{g}), \mathrm{P}=$ leaf extract $\mathrm{pH}, \mathrm{R}=$ relative water content (\%)

The above obtained APTI values were categorised into 04 classes of tolerance level as follows as suggested by [24] and [25]:

1. Tolerant (T or grade I): APTI $>$ average $(\mathrm{APTI}+\mathrm{SD})$.

2. Moderately tolerant (MT or grade II): average $\mathrm{APTI}<\mathrm{APTI}<$ average (APTI $+\mathrm{SD})$. 

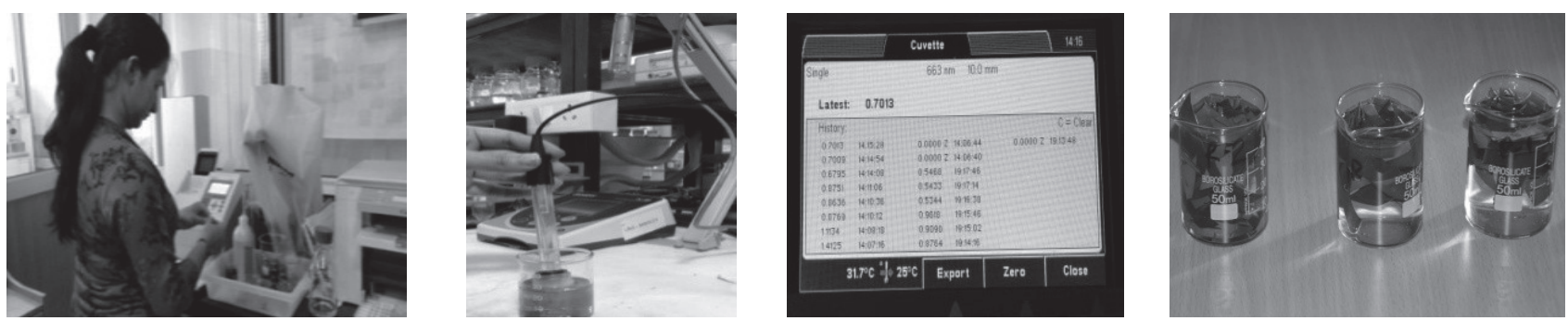

Fig. 2. Estimation of biochemical parameters.

3. Intermediate (I or grade III): average APTI$\mathrm{SD}<\mathrm{APTI}<$ average APTI.

4. Sensitive (S): APTI $<$ average (APTI-SD).

For calculating ranges of APTI values for each plant, mean APTIs and its standard deviation were derived separately. The APTI calculation requires estimation of ascorbic acid, total chlorophyll, leaf extract $\mathrm{pH}$, and relative water content. It is based on above four parameters and thus details on other physiochemical parameters and trace matters are not required. It does not measure pollutant removal efficiency but indicates the sensitivity and tolerance of plants towards the air contaminators. The description of indoor pollutants, such as aromatic (benzene, toluene), halogenated hydrocarbon trichloroethylene xylene, ozone, formaldehyde, ammonia, eradicated by the above mentioned selected plants species are described in Table 3.

\section{Results and Discussion}

Plants are constantly exposed to the environment and they are forced to consume, collect and integrate pollutants that affect their foliar surfaces [26]. They thus display noticeable changes depending on their level of sensitivities [27]. The analyzed values for the above four biochemical parameters along with the derived APTI values and grading have been presented in Table 2.

\section{Ascorbic Acid (AA)}

Foliar ascorbic acid is generally accepted as a good biomonitoring agent [28]. AA is a strong reluctant that stimulates several physiological and defensive mechanisms [29] and defends plants from the deleterious effects of air pollutants [30]. It plays

Table 2. Mean values of biochemical parameters $( \pm$ S.E) with tolerance index of leaf samples.

\begin{tabular}{|c|c|c|c|c|c|c|}
\hline Plant Name & TC $(\mathrm{mg} / \mathrm{g})$ & RWC $(\boldsymbol{\%})$ & $\mathrm{pH}$ & $\mathrm{AA}(\mathrm{mg} / \mathrm{g})$ & APTI & Grades \\
\hline Dypsis lutescens & $1.28 \pm 0.10$ & $51.44 \pm 0.20$ & $5.83 \pm 0.10$ & $3.27 \pm 0.07$ & 7.47 & $\mathrm{~S}$ \\
\hline Philodendron bipinnatifidum & $2.76 \pm 0.19$ & $67.96 \pm 0.77$ & $6.25 \pm 0.03$ & $4.96 \pm 0.16$ & 11.27 & MT \\
\hline Sansevieria trifasciata & $1.96 \pm 0.01$ & $68.01 \pm 0.38$ & $5.51 \pm 0.38$ & $5.84 \pm 0.05$ & 11.17 & MT \\
\hline Rhapis excelsa & $0.94 \pm 0.03$ & $53.37 \pm 0.27$ & $5.61 \pm 0.17$ & $4.95 \pm 0.03$ & 8.58 & $\mathrm{~S}$ \\
\hline Chamaedorea seifrizii & $2.22 \pm 0.09$ & $56.36 \pm 0.82$ & $5.83 \pm 0.13$ & $3.53 \pm 0.21$ & 8.47 & $\mathrm{~S}$ \\
\hline Ficus benjamina & $1.64 \pm 0.11$ & $70.53 \pm 0.55$ & $7.31 \pm 0.05$ & $5.74 \pm 0.13$ & 12.19 & $\mathrm{~T}$ \\
\hline Ficus elastica & $1.18 \pm 0.18$ & $73.7 \pm 0.44$ & $6.48 \pm 0.09$ & $4.34 \pm 0.12$ & 10.7 & MT \\
\hline Chlorophytum comosum & $1.46 \pm 0.13$ & $73.45 \pm 0.12$ & $5.9 \pm 0.04$ & $4.03 \pm 0.07$ & 10.32 & $\mathrm{I}$ \\
\hline Epipremnum aureum & $0.57 \pm 0.13$ & $71.18 \pm 0.41$ & $6.60 \pm 0.09$ & $5.91 \pm 0.04$ & 11.34 & MT \\
\hline Gerbera jamesonii & $1.95 \pm 0.15$ & $44.96 \pm 0.19$ & $5.80 \pm 0.07$ & $2.93 \pm 0.04$ & 6.76 & $\mathrm{~S}$ \\
\hline Spathiphyllum wallisii & $1.66 \pm 0.04$ & $68.94 \pm 0.19$ & $6.3 \pm 0.07$ & $5.65 \pm 0.04$ & 11.4 & MT \\
\hline Dieffenbachia seguine & $1.25 \pm 0.09$ & $80.35 \pm 0.23$ & $6.1 \pm 0.02$ & $4.32 \pm 0.24$ & 11.21 & MT \\
\hline Chrysanthemum indicum & $1.14 \pm 0.01$ & $81.52 \pm 0.08$ & $6.2 \pm 0.03$ & $3.55 \pm 0.06$ & 10.76 & MT \\
\hline Hedera helix & $2.88 \pm 0.02$ & $63.23 \pm 0.29$ & $6.41 \pm 0.03$ & $4.94 \pm 0.15$ & 10.92 & MT \\
\hline Dracaena deremensis & $1.96 \pm 0.31$ & $80.76 \pm 0.57$ & $6.43 \pm 0.03$ & $5.90 \pm 0.04$ & 13.03 & T \\
\hline
\end{tabular}

TC-total chlorophyll; RWC- relative water content; AA- ascorbic acid

S- Sensitive; MT- Moderately tolerant; I- Intermediate; T- Tolerant 
Table 3. Selected indoor plants and pollutants eradicated by them (Chauhan et al., 2015).

\begin{tabular}{|c|c|c|c|c|c|c|c|c|}
\hline S.No & Plant & Benzene & Ozone & $\begin{array}{c}\text { Toulene } \\
\text { and Xylene }\end{array}$ & $\begin{array}{l}\text { Formal } \\
\text { dehyde }\end{array}$ & $\begin{array}{l}\text { Tri chloro } \\
\text { ethylene }\end{array}$ & Ammonia & $\begin{array}{l}\text { Hydro } \\
\text { carbon }\end{array}$ \\
\hline 1 & D. lutescens & $x$ & $x$ & $\checkmark$ & $\checkmark$ & $x$ & $x$ & $x$ \\
\hline 2 & H. helix & $\checkmark$ & $x$ & $\checkmark$ & $\checkmark$ & $x$ & $\checkmark$ & $\checkmark$ \\
\hline 3 & C. comosum & $x$ & $\checkmark$ & $\checkmark$ & $\checkmark$ & $x$ & $x$ & $\checkmark$ \\
\hline 4 & E. pinnatum & $\checkmark$ & $x$ & $\checkmark$ & $\checkmark$ & $x$ & $x$ & $x$ \\
\hline 5 & S. wallisii & $x$ & $x$ & $\checkmark$ & $\checkmark$ & $x$ & $x$ & $x$ \\
\hline 6 & F. benjamina & $x$ & $x$ & $\checkmark$ & $\checkmark$ & $x$ & $x$ & $\checkmark$ \\
\hline 7 & S. trifasciata & $\checkmark$ & $\checkmark$ & $\checkmark$ & $\checkmark$ & $\checkmark$ & $x$ & $x$ \\
\hline 8 & D. deremensis & $\checkmark$ & $x$ & $x$ & $\checkmark$ & $\checkmark$ & $x$ & $x$ \\
\hline 9 & C. indicum & $\checkmark$ & $x$ & $\checkmark$ & $\checkmark$ & $\checkmark$ & $\checkmark$ & $x$ \\
\hline 10 & G. jamesonii & $\checkmark$ & $x$ & $x$ & $\checkmark$ & $\checkmark$ & $x$ & $x$ \\
\hline 11 & R. excelsa & $x$ & $x$ & $\checkmark$ & $\checkmark$ & $x$ & $\checkmark$ & $x$ \\
\hline 12 & F. elastica & $x$ & $x$ & $x$ & $\checkmark$ & $x$ & $x$ & $x$ \\
\hline 13 & P. bipinnatifidum & $x$ & $x$ & $x$ & $\checkmark$ & $x$ & $x$ & $\checkmark$ \\
\hline 14 & C. seifrizii & $x$ & $x$ & $\checkmark$ & $\checkmark$ & $x$ & $x$ & $x$ \\
\hline 15 & D. seguine & $x$ & $x$ & $\checkmark$ & $x$ & $x$ & $x$ & $\checkmark$ \\
\hline
\end{tabular}

a pivotal role in photosynthesis (fixation of carbon dioxide), cell wall stability and division of cells [31, 32]. Adequate AA promotes protective properties and pollutant degradation in plants [33]. AA was given the highest priority as a multiplication factor because its reducing power was directly proportionate to its concentration. In the present study highest ascorbic acid was recorded in Dracaena deremensis $(5.90 \pm 0.04)$ and the lowest was in Gerbera jamesonii (2.93 \pm 0.04$)$. In stressful environments, increased levels of AA defend chloroplast against the aggregation of $\mathrm{H}_{2} \mathrm{O}_{2}, \mathrm{O}_{2}$ and $\mathrm{OH}$ produced by $\mathrm{SO}_{2}$ [19].

\section{Total Chlorophyll (TC)}

TC (mg/g) is widely used as an index of photosynthesis development, production, and biomass competitive features [34]. It evaluates the effect of air pollutants on photosynthesis levels in plant leaves [35]. The chlorophyll concentration varies from species to species. In the subsequent analysis, it has been observed that TC ranged between $0.57 \pm 0.13 \mathrm{mg} / \mathrm{g}$ (Epipremnum aureum) to $2.88 \pm 0.02 \mathrm{mg} / \mathrm{g}$ (Hedera helix). Higher chlorophyll content might favor the plants to better tolerate pollution.

\section{Leaf Extract $\mathrm{pH}$}

PH-dependency is largely due to photosynthetic capacity. Plant photosynthetic effectiveness is reduced at low $\mathrm{pH}$ [36]. Thus, $\mathrm{pH}$ and $\mathrm{TC}$ were added together and then multiplied with AA content in the APTI formula [37]. The mean value of leaf extract $\mathrm{pH}$ ranged from $7.31 \pm 0.05$ (Ficus benjamina) to $5.51 \pm 0.38$ (Sansevieria trifasciata) Low leaf extract $\mathrm{pH}$ is associated with air pollution susceptibility [38, 39].

\section{Relative Water Content (RWC)}

RWC is the total value of leaf water in relation to its fully turgid state. A large amount of water ensures that the physiological equilibrium of the plant is maintained under stresse conditions such as air pollution [40]. The RWC is generally associated with the cell's protoplasmic permeability [41] and the decrease of the RWC limits the transpiration level of leaves. Thus the plants are unable to transfer minerals from the roots to the leaves where biosynthesis takes place, resulting in senescence of leaves [42]. RWC was lowest in Gerbera jamesonii (44.96 \pm 0.19$)$ and it was highest in Chrysanthemum indicum (81.52 \pm 0.08$)$.

\section{Air Pollution Tolerance Index (APTI) and Gradation of APTIs}

APTI values play a major role in determining the vulnerability and resistivity of plants towards air pollutants [43]. According to the gradation of APTI, the plants were classified into 4 categories such as Tolerant (T), Moderately Tolerant (MT), Intermediate (I), and Sensitive (S). Overall mean APTI recorded was $10.37 \pm 1.76$ and out of 15 plant species, only 2 species Dracaena deremensis (APTI 13.03) and Ficus 

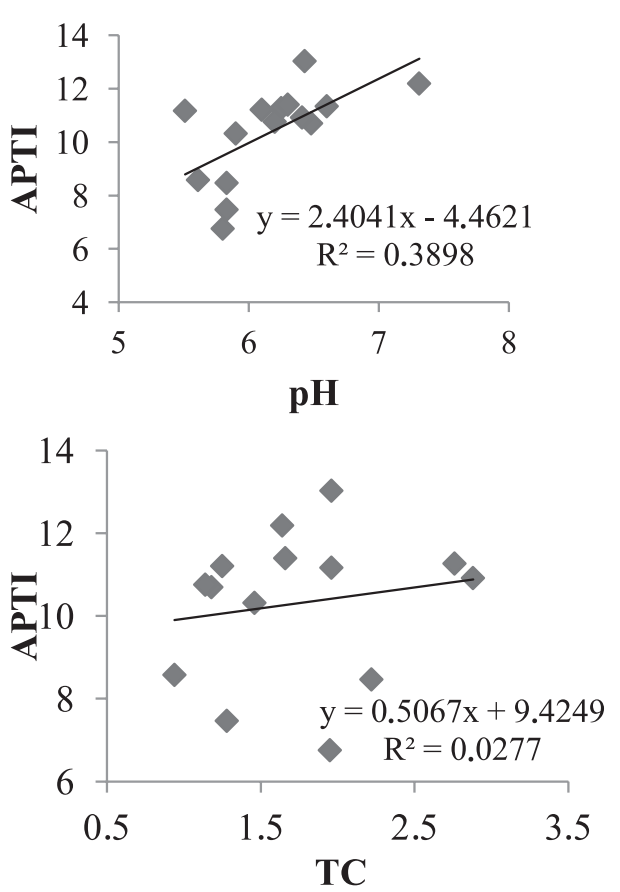
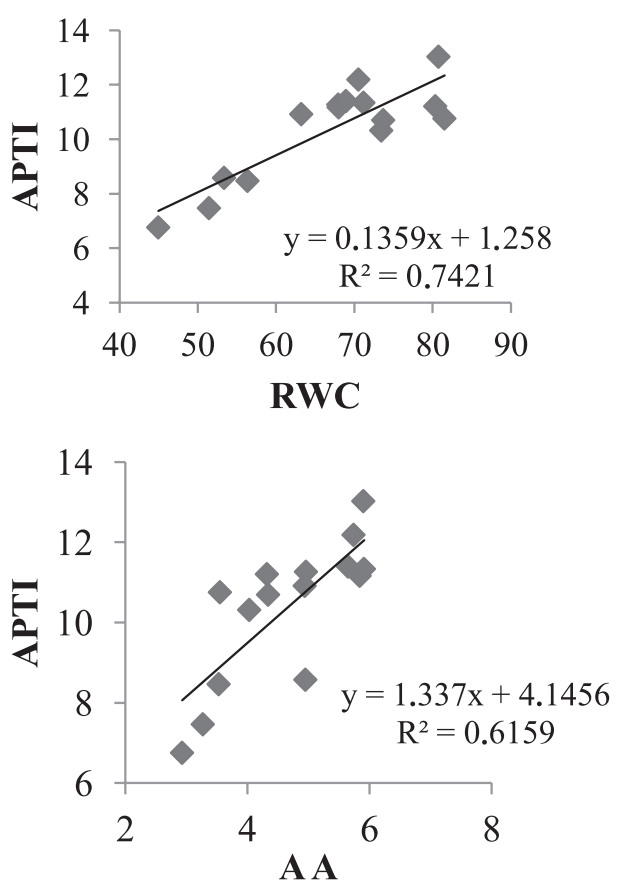

Fig. 3. Linear regression of APTI with different biochemical parameters.

benjamina (APTI 12.19) were found as tolerant. These results are in harmony with EL Sadek et al (2015). Agarwal (2017) also found Ficus benjamina as tolerant species for indoor air pollution. The resulted indicator (sensitive) species were Raphis excelsa (APTI 8.58), Chamaedorea seifrizii (APTI 8.47), Dypsis lutescens (APTI 7.47) and Gerbera jamesonii (APTI 6.76). The 08 species were observed as moderately tolerant namely Spathiphyllum wallisii (APTI 11.4), Epipremnum aureum (APTI 11.34), Philodendron bipinnatifidum (APTI 11.27), Dieffenbachia segulne (APTI 11.21), Sansevieria trifasciata (APTI 11.17), Hedera helix (APTI 10.92), Chrysanthemum indicum (APTI 10.76), and Ficus elastica (APTI 10.7). One plant Chlorophytum comosum (APTI 10.32) was identified as intermediately tolerant.

Planting indoor plants would definitely help in up-gradation of indoor air quality. The ability of selected plants to eradicate 07 common indoor pollutants has been depicted in the Table 3. Among the screened plants Sansevieria trifasciata, Hedera helix and Chrysanthemum indicum can eradicate five pollutants followed by Chlorophytum comosum (four pollutants). Ficus elastica has the least tendency to eradicate only one pollutant. Among seven pollutants formaldehyde was reduced by generally all the studied plants and ozone was reduced by two plants. Hedera helix can also effectively remove aromatic (benzene and toluene), aliphatic (octane) and halogenated (trichloroethylene) hydrocarbons [11]. Hedera helix has the highest benzene removal efficiency $(90 \%)$ followed by Spathiphyllum wallisii (80\%). The Chlorophytum comosum can remove up to $86 \%$ of formaldehyde [44].

\section{Statistical Analysis}

Fig. 3 shows the linear regression graph of APTI along with 4 biochemical parameters. A positive and high correlation were obtained between APTI and relative water content $\left(\mathrm{R}^{2}=0.742\right)$, and APTI and Ascorbic acid $\left(\mathrm{R}^{2}=0.615\right)$. A weak and positive correlation were seen between APTI and total chlorophyll $\left(\mathrm{R}^{2}=0.027\right)$, and APTI and leaf extract $\mathrm{pH}\left(\mathrm{R}^{2}=0.389\right)$. The high APTI values is indicative of high pollution tolerance and for such cases relative water content and Ascorbic acid are reported to be higher in comparison to total chlorophyll and $\mathrm{pH}$ [45]. Also, high ascorbic acid content in leaf increases to combat the stressed conditions. This highlights the significance of biochemical factors that essentially determine the resilience of plant species. It was found that each physiological and biochemical parameter plays a major part in the calculation of the tolerance level of plants as all these parameters showed positive correlations with APTI.

\section{Conclusion}

Indoor air pollution is a serious environmental concern, which is given lesser emphasis as compared to outdoor air pollution thus, requiring scientific interventions for its management. The negative consequences of indoor air pollution require proper legislation and increased research work. The use of pollution abatement indoor potted plants is one of such remedies, which has the competency to absorb 
indoor air pollutants. Estimation of APTI for such plants provides a reliable method for selection of indoor plants, which can be used as mitigator and bioindicator of indoor air pollutions. This work helped in the estimation of pollution tolerance capability of widely used indoor potted ornamental plants. In our study, Dracaena deremensis appeared as the most tolerant species and Gerbera jamesonii has lowest APTI. Plant species vary in their tolerance levels and no discernible trend recorded in APTI values with the RWC, ascorbic acid, chlorophyll content and $\mathrm{pH}$ of leaf extracts. Though the RWC, ascorbic acid, chlorophyll content and $\mathrm{pH}$ of leaf extract showed associations with APTI indicating each physiological and biochemical parameter plays an important role in evaluating the rates of the vulnerability of the plant species due to pollution. Thus, the implementation of potted plants is a promising and better technique in the field of indoor air pollution control.

\section{Acknowledgments}

This project is funded by Council of Scientific and Industrial Research (CSIR), ministry of science \& technology, government of India, under Agri-nutribiotech mission mode NCP projects entitled 'High resolution NextGen remote sensing for medicinal, aromatic and commercially important crops (MLP$160)$ ' and 'UAV based high resolution remote sensing for modernized and efficient cultivation practices of commercially important medicinal and aromatic crops (MLP-139)'. The authors would like to thank Dr. Sanjay Kumar, Director, CSIR-IHBT, Palampur, India, for his guidance and support in carrying out this research. Staff members of Environmental Technology and Agrotechnology divisions are acknowledged for their help in field work and laboratory. The CSIR-IHBT communication number is 4550 .

\section{Conflict of Interest}

The authors declare no conflict of interest.

\section{References}

1. CRUZ M.D., CHRISTENSEN J.H., THOMSEN J.D., MULLER R. Can ornamental potted plants remove volatile organic compounds from indoor air? - a review. Environmental Science and Pollution Research. 21 (24), 13909, 2014.

2. TORPY F.R., IRGA P.J., BURCHETT M. D. Profiling indoor plants for the amelioration of high $\mathrm{CO}_{2}$ concentrations. Urban Forestry and Urban Greening. 13 (2), 227, 2014.

3. SRIPRAPAT W., SUKSABYE P., AREEPHAK S., KLANTUP P., WARAHA A., SAWATTAN A., THIRAVETYAN P. Uptake of toluene and ethylbenzene by plants: Removal of volatile indoor air contaminants. Ecotoxicology and Environmental Safety. 102, 147, 2014.

4. SOREANU G., DIXON M. DARLINGTON A. Botanical biofiltration of indoor gaseous pollutants - A mini-review. Chemical Engineering Journal. 229, 585, 2013.

5. Household air pollution and health. www.who.int (9 June 2021).

6. ROHRA H., TANEJA A. Indoor air quality scenario in India-An outline of household fuel combustion. Atmospheric Environment. 129, 243, 2016.

7. IRGA P.J., TORPY F.R., BURCHETT M.D. Can hydroculture be used to enhance the performance of indoor plants for the removal of air pollutants? Atmospheric Environment 77, 267, 2013.

8. KIM B.M., PARK J.S., KIM S.W. Source apportionment of PM10 mass and particulate carbon in the Kathmandu Valley, Nepal. Atmospheric Environment. 123, 190, 2015.

9. KAPOOR M. Managing Ambient Air Quality Using Ornamental Plants-An Alternative Approach. Universal Journal of Plant Science. 5 (1), 1, 2017.

10. ZHANG J., SMITH K.R. Indoor air pollution: a global health concern. British Medical Bulletin. 68 (1), 209, 2003.

11. YANG D.S., PENNISI S., SON K.C., KAYS S. Screening Indoor Plants for Volatile Organic Pollutant Removal Efficiency. Hortscience. 44 (5), 1377, 2009.

12. LEE M., LEE J., PARK B., MIYAZAKI Y. Interaction with indoor plants may reduce psychological and physiological stress by suppressing autonomic nervous system activity in young adults: a randomized crossover study. Journal of Physiological Anthropology. 34, 21, 2015.

13. MADAN S., CHAUHAN S. Air Pollution Tolerance Index and Anticipated Performance Index of Selected Plant Species in Haridwar City, India. Report and Opinion. 7 (6), 32, 2015.

14. CHAUDHARY S., PANWAR J. Evaluation of air pollution status and anticipated performance index of some tree species for green belt development in the holy city of Kurukshetra, India. International Journal for Innovative Research in Science and Technology. 2, 269, 2016.

15. ACHAKZAI K., KHALID S., ADREES M., BIBI A., ALI S., NAWAZ R., RIZWAN M. Air pollution tolerance index of plants around brick kilns in Rawalpindi, Pakistan. Journal of Environmental Management. 190, 252, 2017.

16. RAI P.K., PANDA L.L.S. Dust capturing potential and air pollution tolerance index (APTI) of some road side tree vegetation in Aizawl, Mizoram, India: an Indo-Burma hotspot region. Air Quality, Atmosphere and Health. 7 (1), 93, 2014.

17. EL-SADEK M., KORIESH E., EL-FATAH Y. A., MOGHAZY E., FUJII E. Correlation between some components of interior plants and their efficiency to reduce Formaldehyde, Nitrogen and Sulfur Oxides from indoor air. International Research Journal of Plant Science. 3 (10), 222, 2012.

18. CHAUHAN P., RAWAT M.S. GAUBA P. Role of Plants in Indoor Air Remediation. International Journal of Engineering Technology Science and Research. 4 (9), 749, 2015.

19. CHOUHAN A., IQBAL S., MAHESHWARI R.S., BAFNA A. A study of air pollution tolerance index of plants growing in Pithampur industrial area sector 1,2 and 3. Research Journal of Recent Sciences. 1, 172, 2012.

20. WEATHERLY P.E. Examination of the relative turgidity technique for estimating water deficit in leaves. Journal of Biological Sciences. 15, 413, 1965. 
21. SADASIVAM S. MANICKAM A. In Biochemical methods for agriculture science. New age International Pvt. Ltd. New Delhi. 195, 1992.

22. GOVINDARAJU M., GANESHKUMAR R.S., MUTHUKUMARAN V.R., VISVANATHAN P. Identification and evaluation of air pollution- tolerant plants around lignite-based thermal power station for greenbelt development. Environmental Science and Pollution Research. 19 (4), 1210, 2012.

23. OGUNKUNLE C.O., SULEIMAN L.B., OYEDEJI S., AWOTOYE O.O., FATOBA P.O. Assessing the air pollution tolerance index and anticipated performance index of some tree species for biomonitoring environmental health. Agroforestry Systems. 89 (3), 447, 2015.

24. LIU Y.J., DING H. Variation in air pollution tolerance index of plants near a steel factory: implication for landscape plant species, selection for industrial areas. Wseas transactions on Environment and Development. 4 (1), 24, 2008.

25. ZHANG P.Q., LIU Y.J., CHEN X., YANG Z., ZHUM.H., LI Y.P. Pollution resistance assessment of existing landscape plants on Beijing streets based on air pollution tolerance index method. Ecotoxicology and Environmental Safety. 132, 212, 2016.

26. NOOR M.J., SULTANA S., FATIMA S., AHMAD M., ZAFAR M., SARFRAZ M., BALKHYOUR M.A., SAFI S.Z., ASHRAF M.A. Estimation of anticipated performance index and air pollution tolerance index and of vegetation around the marble industrial areas of Potwar region: bioindicators of plant pollution response. Environmental Geochemistry and Health. 37 (3), 441, 2015.

27. AGARWAL A. Evaluation of Indoor Plants for their Pollution Tolerance Ability. Journal of Ecology and Environmental Sciences. 5 (3), 21, 2017.

28. BORA M., JOSHI N. A study on variation in biochemical aspects of different tree species with tolerance and performance index. The Bioscan. 9 (1), 59, 2014.

29. RAZA S.H., MURTHY M.S.R. Air pollution tolerance index of certain plants of Nacharam Industrial Area, Hyderabad. Indian Journal of Botanical Research. 11 (1), 91, 1988

30. GHOSH P.K., DE T.K., MAITI T.K. Ascorbic acid production in root, nodule and Enterobacter spp. (Gammaproteobacteria) isolated from root nodule of the legume Abrus precatorius L. Biocatalysis and Agricultural Biotechnology. 4 (2), 127, 2014.

31. PALIT D., KAR D., MISRA P., BANERJEE A. Assessment of air quality using several biomonitor of selected sites of Duragapur, Burdwan district by air pollution tolerance index approach. Indian Journal of Scientific Research. 4 (1), 149, 2013.

32. SANGHI S.B., SHARMA C., SANGHI S.K. Comparison of APTI values of some medicinal plants of industrial areas and Ratapani wild life sanctuary in Raisen district of Madhya Pradesh. International Journal of Pharmaceutical and Life Sciences. 6 (1), 4157, 2015.
33. DAS S.K., JAYANTA K.P., HRUDAYANATH T. Antioxidative Response to Abiotic and Biotic Stresses in Mangrove Plants. International Review of Hydrobiology. 101 (1-2) 3, 2016.

34. JIN X.L., WANG K. R., XIAO C.H., DIAO W. Y., WANG F.Y., CHEN B., LI S. K. Comparison of two methods for estimation of leaf total chlorophyll content using remote sensing in wheat. Field Crop Research. 135, 24, 2012.

35. NINAVAE S.Y., CHAUDHARI P.R., GAJGHATE D.G., TARAR J.T. Foliar biochemical features of plants as indicators of air pollution. Bulletin of environmental contamination and toxicology. 67, 133, 2001.

36. BHARTI S.K., TRIVEDI A., KUMAR N. Air pollution tolerance index of plants growing near an industrial site. Urban Climate. 24, 820, 2018.

37. YAN-JU L., HUI D. Variation in air pollution tolerance index of plant near a steel factory: implications for landscape-plant species selection for industrial areas. Environmental Development. 1, 24, 2008.

38. REHMAN R., GUL A. Plant-pollutant interaction. In book Plants, Pollutants and Remediation. Münir Öztürk, Muhammad Ashraf, Ahmet Aksoy, MSA. Ahmad, and Khalid Rehman Hakeem, eds. Springer, Netherlands, 213, 239, 2015.

39. PANDEY A.K., PANDEY M., MISHRA A., TIWARY S.M., TRIPATHI B.D. Air pollution tolerance index and anticipated performance index of some plant species for development of urban forest. Urban Forestry and Urban Greening. 14, 866, 2015.

40. SHARMA M., PANWAR N., ARORA P., LUHACH J., CHAUDHRY S. Analysis of biological factors for determination of air pollution tolerance index of selected plants in Yamuna Nagar, India. Journal of Environmental Biology. 34, 509, 2013.

41. NAYAK D., PATEL, D.P., THAKARE H.S., SATASHIYA K., SHRIVASTAVA P.K. Evaluation of air pollution tolerance index of trees. Research in Environment and Life Sciences. 8 (1), 7, 2014.

42. TSEGA Y.C., DEVI-PRASAD A.G. Variation in air pollution tolerance index and anticipated performance index of roadside plants in Mysore, India. Journal of Experimental Biology. 35, 185, 2014.

43. NAYAK D., PATEL D.P., THAKARE H.S., SATSIYA K., SRIVASTAVA P.K. Assessment of air pollution tolerance index of selected plants. Indian Forester 141 (4), 372, 2015.

44. PIPAL A. S., KUMAR A., JAN R., TANEJA A. Role of Plants in Removing Indoor Air Pollutants. In book Chemistry of Phytopotentials: Health, Energy and Environmental Perspectives, Khemani L.D., Srivastava M.M., Srivastava S., Springer Heidelberg Dordrecht London New York, 319, 2012.

45. RAI P.K., PANDA L.L.S., CHUTIA B.M., SINGH M.M. Comparative assessment of air pollution tolerance index (APTI) in the industrial (Rourkela) and non industrial area (Aizawl) of India: An ecomanagement approach. African Journal of Environmental Science and Technology. 7 (10), 944, 2013. 